\title{
THE BIBLIOMETRIC ANALYSIS OF LITERATURE ON MUSEUM STUDIES
}

\author{
C. W. Kuo ${ }^{\text {a }}$, Y. H. Yang ${ }^{\text {a, } *}$ \\ ${ }^{a}$ National Palace Museum, Department of Education, Exhibition and Information Service, Taipei City 11143, Taiwan (R.O.C.) - \\ (paulkuo, syang101)@ npm.gov.tw
}

Commission VI, WG VI/4

KEY WORDS: Museum studies, Museology, Bibliometrics, Bradford's Law

\begin{abstract}
:
Museum studies, is the study of museums, museum curation, and how and why museums developed into their institutional role in education and culture through scientific, social, political and other related forces. The purpose of this study is to shed light on the application trends of the international literature related to museum studies on the SCIE, SSCI, and AHCI databases between 1995 and 2014 using a bibliometric technique and citation analysis. The results of this study reveal that influences of the literature related to museum studies on other subject areas continue to expand. Considering the publication of major countries, subject areas, journal and institutions, the results also discussed that the future trend through analysing most cited articles. Moreover, 12 core journal lists are identified by Bradford's law.
\end{abstract}

\section{INTRODUCTION}

Academic research is the process of knowledge transfer, accumulation and innovation, while it also motivates and measures the importance of one discipline development. Through its development, the academic research can lift the veil of one discipline dynamics and speculate about the future trend. It also exerts its influence and demonstrates the value of one discipline through the dissemination of scholarly research results. Furthermore, academic spread is the process that scholars in various disciplines communicate through formal and informal dissemination of information. The research results can be presented and be developed chronically in all subject areas with different forms of the published literature. Among published results, papers which have novel and fast-spreading characteristics, is the most important scholarly communication pipeline spread. Providing the most valuable information in the research process, journal articles also help the researchers in forming their academic achievement. Therefore, the development of one discipline can be observed from the journals published literature and publishing research results. And its future trend and evolution also can be explored through spreading of journal articles in various disciplines.

Thus, Canadian Museum of Civilization shares its Research Policy with various museums. It also has set the policy to perform studying and researching to enhance the responsibility and obligation of the museum, which should actively encourage researchers to publish their performances through the exhibition, publishing, electronic media, lectures and other activities (Brandon and Wilson 2005). Whether museum studies can be recognized in the world as a subject area, its professional literature is an issue that measures the significant growth in the museum world and should be obtained more attention (Lorente 2012). The number of published literature is the important measure of the development of one discipline. Increasing related published works is another important phenomenon that shows the booming of museum studies. Especially, the journal articles published in scholarly communication is an important pipeline, and also a measurable standards and quality of a research disciplines through the evaluation and analysis of relevant research and development.

Bibliometric methods in analyzing academic development have been exited for many years, mainly uses the quantitative and statistical analysis of published literature. It also shows various disciplines characteristics and model of development. Thus, the future trend of one discipline could be forecasted by examining the origins and progress of one discipline.

The explorations of the museum studies literature have seen vigorous development in the last decade owing to the convenience and advancements of museum studies tools. There is little review on museum studies. Some researchers reviewed on family experience on museums (Borun, Cleghom, and Garfield 1995, Dierking 1989, Kropf 1989, Sterry and Beaumont 2006), while (Kawashima 1998) focused on the museum marketing and its impacts. Borun, Cleghom, and Garfield (1995) reviewed family learning through a web survey of art museum educators and a comprehensive literature. Jones (1998) discussed the museums development through bibliometric methods However, computer technology rapidly developed in recent year, especially in 10 years. For example, web 2.0, social networking, cloud computing, smart phones, big data, internet of things, etc will change our experiences on museum. We explored the trends of museum-related studies by means of bibliometric reviews of the literature in the SCIE (Science Citation Index Expanded), SSCI (Social Science Citation Index) and AHCI (Arts and Humanity Citation Index) databases between 1995 and 2014. Standard bibliometric indicators such as the number of papers, number of authors, productivity by country, institutional collaboration, and most cited articles will be analyzed. Moreover, we use the Bradford's law to define the core journal lists on the museum-related studies.

\section{DATASET AND METHOD}

The dataset used in this study was derived from the SCIE (Science Citation Index Expanded), SSCI (Social Sciences

* Corresponding author 
Citation Index) and AHCI (Arts \& Humanities Citation Index) databases of the Web of Science, created by the Institute for Scientific Information. Thus, this dataset cover science, social science, art and humanity fields. SCIE covers more than 8,500 notable journals encompassing 150 disciplines. Coverage is from the year 1900 to the present day. SSCI covers more than 3,000 journals in social science disciplines. Range of coverage is from the year 1900 to the present day. AHCI covers more than 1,700 arts and humanities journals with 250 major scientific and social sciences journals starting from 1975.

An empirical search command was used by "Topic= ("museum stud*") OR Topic=("Museology") OR Title=("museum*") refined by Document Type $=($ ARTICLE OR REVIEW OR ART EXHIBIT REVIEW)" to retrieve data related to museum studies. The documents specifically included articles and reviews in the study. Book reviews, papers of the proceeding, letters, notes, and meeting abstracts were not taken into consideration. A total of 8,947 papers published between 1995 and 2014 were found.

Citation analysis is one of important research areas in Bibliometrics. The relationship between literature and the literature of the subject content can be found out through the correlation analysis on the cited information in the literature. One method is to use a direct calculation of total literature citations, as well as calculating the citation of one author's works, or one specific publication, to analyze and evaluate the overall trend

Samuel C. Bradford introduced Bradford's Law in 1934 which is based on a pattern that estimates the exponentialldiminishing returns of extending a search for references in science journals. The principle imposes a formulation that if journals within a field are sorted based on the number of articles into four groups, with each group which is concerned with comprising approximately one-third of all articles, then the number of journals in each group will be proportional to $1: n: n^{2}$ (Wolfram 2003). Bradford's Law (about scattering of subjects in information sources) is often mentioned together with Zipf's Law (about word frequencies in natural language texts) and Lotka's Law (with regard to the distribution of authors' productivity) as one of the three most important bibliometric laws. These three laws are often considered to be the best models or examples of research resources that are available within the Library and Information Sciences (De Bellis 2009).

\section{RESULTS OF BIBLIOMETRIC ANALYSIS}

\subsection{Overview of Productivity}

A total of 8,947 papers related to museum studies were retrieved from the SCIE, SSCI and AHCI databases. Figure 1 shows the number of published papers on the topic of museum studies between 1995 and 2014. According to the numerical data, a large number of research papers published about 20002001 have been catalogued in the databases, with distribution rates of $589(6.58 \%)$ and $593(6.63 \%)$ against the total number of papers in 2000 and 2001, respectively. It has also been observed that a declining trend in these numbers appears to have begun from 2001. Figure 2 shows the number of citations of published papers related to museum studies made each year. The figures suggest that the number of these citations has growing. Museum-related articles seem to render volume reduction trend, but in fact has increased the number cited, indicating that these museum-related articles are widespread to influence the other disciplines.

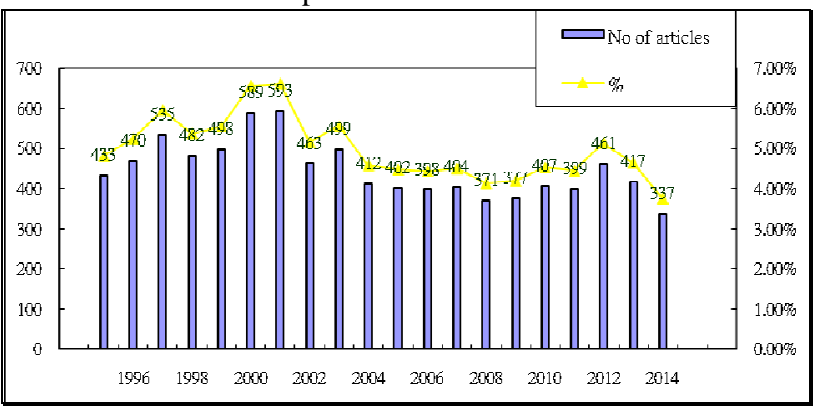

Figure 1. Number of published papers from 1995 to 2014.

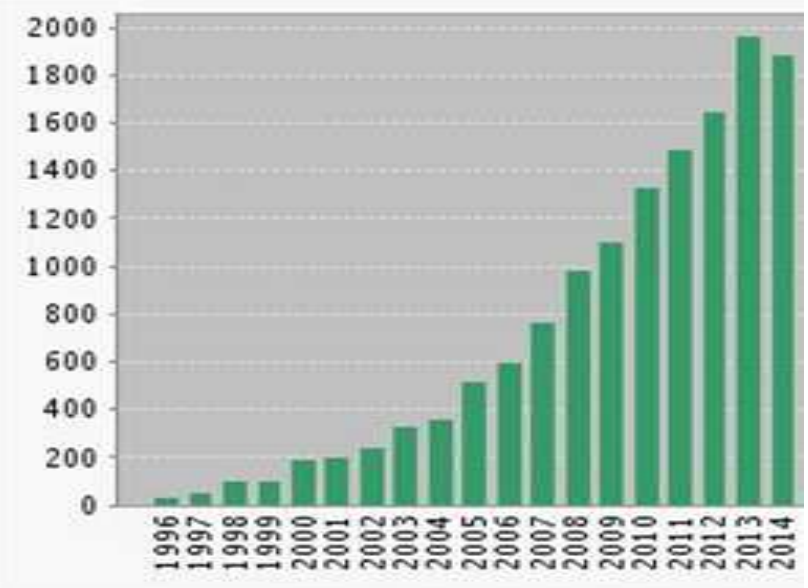

Figure 2. The annual citations of the published papers (retrieved on Feb. 5, 2015 from Web of Science)

Figure 3 illustrates the ten countries ranked as the top publishers of catalogues in the databases. The figure shows that the USA was the dominant country, followed by England and Germany. In contrast to Figure1, Figure 4 illustrates that the article published in the USA declined until 2008 from the peaked in early 2000, then increased gradually, indicating that the publication trend of USA dominates the overall trend.

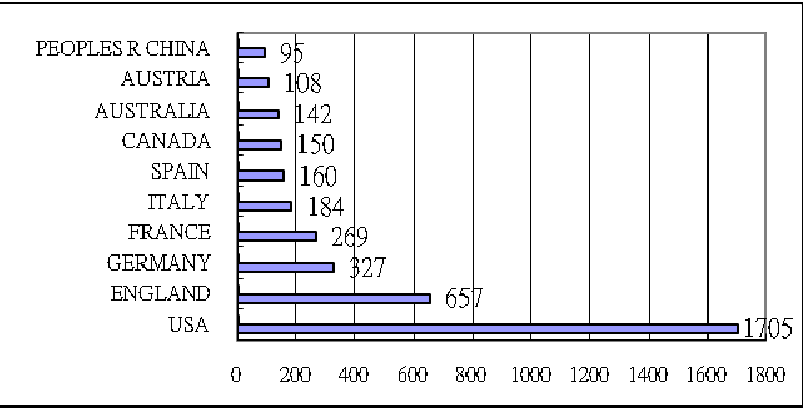

Figure 3. The top 10 most productive countries 


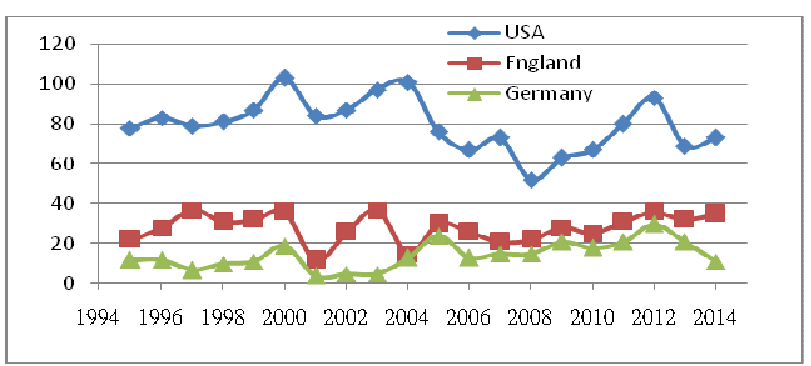

Figure 4 . The yearly publications of top 3 most productive countries

Table 1 presents a more detailed account of the top 10 institutions by which indexed papers were submitted, with the Metropolitan Museum Art, British Museum, Smithsonian Institution as the top 3 most productive institutions. The top 6 institutions The data also show that the corresponding ratios for the institutions in the England are much greater than those in the USA, indicating that the institutions in their countries dominate the academic research in the museum studies field.

\begin{tabular}{|c|l|c|c|c|c|}
\hline Rank & Institution Name & Count & $\%$ & Country & $\begin{array}{c}\% \text { of } \\
\text { country }\end{array}$ \\
\hline 1 & $\begin{array}{l}\text { Metropolitan } \\
\text { Museum Art }\end{array}$ & 81 & $0.91 \%$ & $4.75 \%$ & USA \\
\hline 2 & British Museum & 62 & $0.69 \%$ & $9.44 \%$ & England \\
\hline 3 & $\begin{array}{l}\text { Smithsonian } \\
\text { Inst. }\end{array}$ & 59 & $0.66 \%$ & $3.46 \%$ & USA \\
\hline 4 & $\begin{array}{l}\text { Nat. Hist. } \\
\text { Museum }\end{array}$ & 52 & $0.58 \%$ & $3.05 \%$ & USA \\
\hline 5 & $\begin{array}{l}\text { Victoria Albert } \\
\text { Museum }\end{array}$ & 47 & $0.53 \%$ & $7.15 \%$ & England \\
\hline 6 & $\begin{array}{l}\text { Museum Natl. } \\
\text { Hist. Nat. }\end{array}$ & 44 & $0.49 \%$ & $2.58 \%$ & USA \\
\hline 7 & $\begin{array}{l}\text { NYU } \\
\text { Harvard Univ. }\end{array}$ & 37 & $0.41 \%$ & $2.17 \%$ & USA \\
\hline 9 & $\begin{array}{l}\text { Univ. Calif. } \\
\text { Berkeley }\end{array}$ & 35 & $0.39 \%$ & $2.05 \%$ & USA \\
\hline 10 & Univ. Oxford & 33 & $0.37 \%$ & $5.02 \%$ & England \\
\hline
\end{tabular}

Table 1. Top 10 most productive institutes

Figure 5 provides the top ten subject areas in which museum studies were most widely studied. The most highly ranked subject area was art, with 3621 (approximately 47\%) of total, followed by architecture and arts \& humanities-other topics related to museum studies.

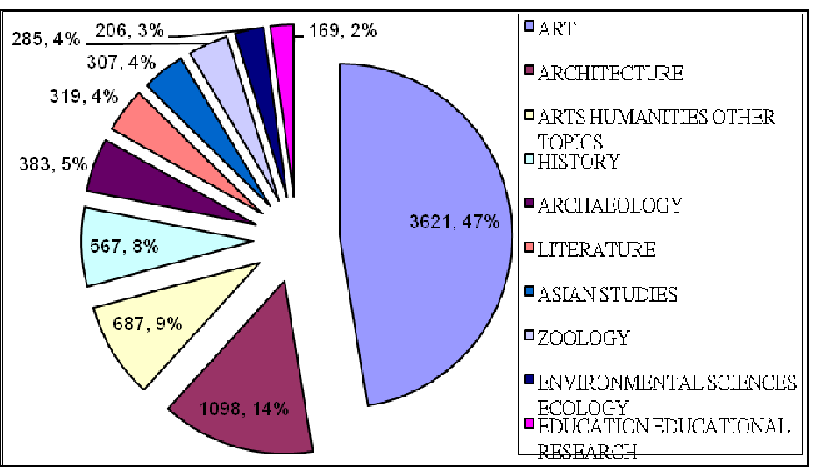

Figure 5: Top 10 subject areas

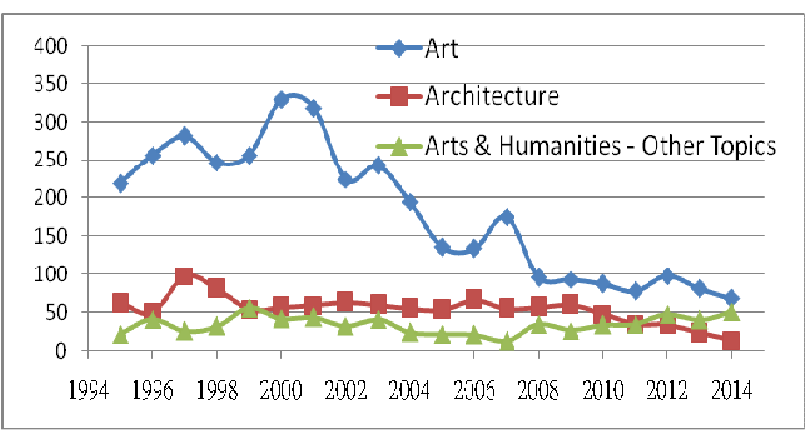

Figure 6: The yearly publication of top 3 subject areas

Table 2 offers an investigation into the authors who have written more than 18 papers in museum studies during 19952014. The most 3 productive authors are Picard, D with 47 written in French, Jodidio, P with 39 in French, Ledes, AE with 35 in English. The data show that the author number in English is more than those in French, while the major subject areas include art and architecture.

\begin{tabular}{|l|c|c|c|}
\hline Author & articles & Language & Subject Area \\
\hline \hline Picard, D & 47 & French & Art \\
\hline Jodidio, P & 39 & French & Art \\
\hline Ledes, AE & 35 & English & Art \\
\hline Cash, S & 34 & English & Art \\
\hline Gustafson, EH & 31 & English & Art \\
\hline Slessor, C & 29 & English & Architecture \\
\hline Gaillemin, JL & 21 & French & Art \\
\hline Webb, M & 20 & English & Architecture \\
\hline Blanc, D & 19 & French & Art \\
\hline Lusaka, J & 18 & English & Art \\
\hline Mcguire, P & 18 & English & Architecture \\
\hline
\end{tabular}

Table 2. The most productive authors

Table 3 shows the 10 articles yielding the most citations. The results revealed that Graham et al. (2004) was an icon in museum studies, with the most citations and highest average citations per year, indicating that it was also the most influential paper. These articles, although not specifically studied on museology itself, but highlight that the museum research will located on the topics about biodiversity, robot tour-guide, museum collections, museum members, species, etc. Among these articles, the two articles especially discussed the robot tour-guiding application on museum (Burgard et al. 1999, Thrun et al. 2000), indicating that the future trend of museum adopting new gadgets .

\begin{tabular}{|l|c|c|}
\hline Articles & $\mathrm{TC}^{1}$ & $\mathrm{ACPY}^{2}$ \\
\hline $\begin{array}{l}\text { Graham et al. (2004) New developments in } \\
\text { museum-based informatics and applications in } \\
\text { biodiversity analysis }\end{array}$ & $\mathbf{3 7 7}$ & $\mathbf{3 1 . 4 2}$ \\
\hline $\begin{array}{l}\text { Bhattacharya, Rao, and Glynn (1995) } \\
\text { Understanding the bond of identification: An } \\
\text { investigation of its correlates among art } \\
\text { museum members }\end{array}$ & $\mathbf{2 4 2}$ & $\mathbf{1 1 . 5 2}$ \\
\hline Moksnes (1995) Egg- morphs and host & $\mathbf{1 7 5}$ & $\mathbf{8 . 3 3}$ \\
\hline
\end{tabular}




\begin{tabular}{|l|l|l|l|}
\hline $\begin{array}{l}\text { preference in the Common Cuckoo (Cuculus } \\
\text { canorus): an analysis of cuckoo and host eggs } \\
\text { from European museum collections }\end{array}$ & & \\
\hline $\begin{array}{l}\text { Thrun et al. (2000) Probabilistic algorithms and } \\
\text { the interactive museum tour-guide robot } \\
\text { minerva }\end{array}$ & $\mathbf{1 6 6}$ & $\mathbf{1 0 . 3 8}$ \\
\hline $\begin{array}{l}\text { Burgard et al. (1999) Experiences with an } \\
\text { interactive museum tour-guide robot }\end{array}$ & $\mathbf{1 6 2}$ & $\mathbf{9 . 5 3}$ \\
\hline $\begin{array}{l}\text { Wandeler, Hoeck, and Keller (2007) Back to } \\
\text { the future: museum specimens in population } \\
\text { genetics }\end{array}$ & $\mathbf{1 4 9}$ & $\mathbf{1 6 . 5 6}$ \\
\hline $\begin{array}{l}\text { Suarez and Tsutsui (2004) The value of } \\
\text { museum collections for research and society }\end{array}$ & $\mathbf{1 3 9}$ & $\mathbf{1 1 . 5 8}$ \\
\hline $\begin{array}{l}\text { Ponder et al. (2001) Evaluation of museum } \\
\text { collection data for use in biodiversity }\end{array}$ & $\mathbf{1 2 5}$ & $\mathbf{8 . 3 3}$ \\
assessment & & \\
\hline $\begin{array}{l}\text { Chown and Gaston (2000) Areas, cradles and } \\
\text { museums: the latitudinal gradient in species } \\
\text { richness }\end{array}$ & $\mathbf{1 2 0}$ & $\mathbf{7 . 5 0}$ \\
\hline $\begin{array}{l}\text { Elith and Leathwick (2007) Predicting species } \\
\text { distributions from museum and herbarium } \\
\text { records using multiresponse models fitted with } \\
\text { multivariate adaptive regression splines }\end{array}$ & $\mathbf{9 6}$ & $\mathbf{1 0 . 6 7}$ \\
\hline
\end{tabular}

Table 3. The 10 most cited articles (data retrieved on Feb. 5, 2015); ${ }^{1} \mathrm{TC}$ : times cited; ${ }^{2} \mathrm{ACPY}$ : average citations per year

\subsection{Bradford's Law and journal literature}

The 8,947 published papers referred to in this study are distributed among 1703 journals. Appendix provides the number of published papers in each journal and other information ranked by the number of published papers according to the zoning of Bradford's Law. Besides, the number of published papers in the top 11 journals is about one-third of the 2,237 published papers $(2,824,32 \%)$. The other 6,123 published papers $(68 \%)$ are distributed among 1,692 journals, including 1 published paper in each of 931 journals. The results show that the distribution of published papers related to museum is decentralized.

Table 4 provides the ratio comparisons of 3 zones, that is the ratio of published papers in each zone for zones $\mathrm{A}, \mathrm{B}, \mathrm{C}$ is 12 : 122 : 1569. The ratio among the first 3 zones $(\mathrm{A}, \mathrm{B}, \mathrm{C})$ is almost equal to $11.5:(11.5)^{2}:(11.5)^{3}$ or $1: 11.5^{1}:(11.5)^{2}$. In other words, A: B: C is approximated to $1: \mathrm{n}: \mathrm{n}^{2}$. The result approximately matches the explanations of Bradford's Law.

\begin{tabular}{|c|c|c|c|c|}
\hline zone & $\begin{array}{c}\text { (1) No. of } \\
\text { journal }\end{array}$ & $\begin{array}{c}\text { (2) No. of } \\
\text { articles }\end{array}$ & $\begin{array}{c}\text { (3) Range } \\
\text { of No. of } \\
\text { articles }\end{array}$ & $\begin{array}{c}\text { (4) Average } \\
\text { articles }\end{array}$ \\
\hline A & 12 & 2824 & $123 \sim 409$ & 235 \\
\hline B & 122 & 3070 & $9 \sim 103$ & 25 \\
\hline C & 1569 & 3053 & $1 \sim 8$ & 2 \\
\hline
\end{tabular}

Table 4. A brief distribution of the literature

Table 5 specifies 12 leading journals which have published the most research papers related to museum studies according to the data distribution, the papers published in these journals take up to nearly one-third of the total amount. Artnews is within the top the list, which has 409 published papers (4.57\%) against the total 8,947 articles. The second journal, Museum International (357 papers, 3.99\%), has more impact on the times of citation rather than the first. It is also observed that the main subject areas comprised of the 12 listed journals are belonging to Art and Architecture.

\begin{tabular}{|c|l|c|c|c|}
\hline Rank & \multicolumn{1}{|c|}{ Journal title } & count & $\%$ & $\begin{array}{c}\text { times } \\
\text { cited }\end{array}$ \\
\hline 1 & Artnews & 409 & $4.57 \%$ & 20 \\
\hline 2 & Museum International & 357 & $3.99 \%$ & 171 \\
\hline 3 & Museum News & 337 & $3.77 \%$ & 78 \\
\hline 4 & Connaissance Des Arts & 326 & $3.64 \%$ & 2 \\
\hline 5 & Arts Of Asia & 217 & $2.43 \%$ & 5 \\
\hline 6 & Art In America & 215 & $2.40 \%$ & 18 \\
\hline 7 & $\begin{array}{l}\text { A+U - Architecture And } \\
\text { Urbanism }\end{array}$ & 204 & $2.28 \%$ & 0 \\
\hline 8 & Architectural Review & 187 & $2.09 \%$ & 4 \\
\hline 9 & Magazine Antiques & 170 & $1.90 \%$ & 8 \\
\hline 10 & Architectural Record & 146 & $1.63 \%$ & 6 \\
\hline 11 & $\begin{array}{l}\text { Revue Du Louvre-La Revue } \\
\text { Des Musees De France }\end{array}$ & 133 & $1.49 \%$ & 2 \\
\hline 12 & $\begin{array}{l}\text { Revue Des Musees De France- } \\
\text { Revue Du Louvre }\end{array}$ & 123 & $1.37 \%$ & 2 \\
\hline
\end{tabular}

Table 5. The 12 core journal titles and their statistics

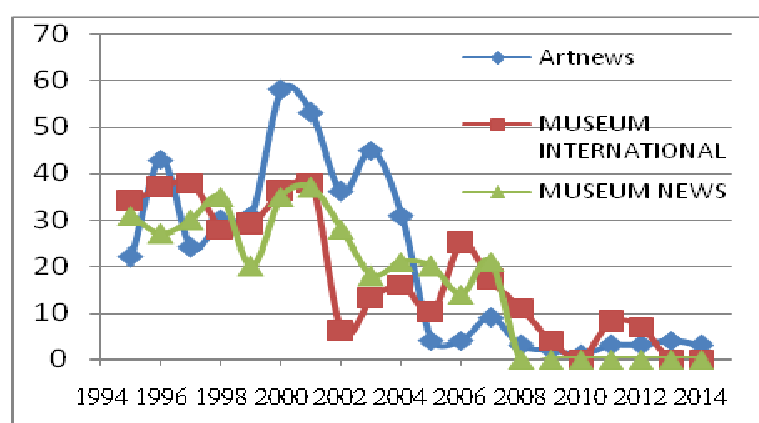

Figure 8: The yearly publication numbers of top 3 journals

\begin{tabular}{|l|c|c|}
\hline \multicolumn{1}{|c|}{ Journal title } & Times cited & Count \\
\hline Trends In Ecology \& Evolution & 646 & 4 \\
\hline Science Education & 369 & 12 \\
\hline Journal Of Marketing & 242 & 1 \\
\hline Journal Of Cultural Heritage & 230 & 47 \\
\hline Conservation Biology & 214 & 5 \\
\hline Journal Of Zoology & 192 & 1 \\
\hline Studies In Conservation & 181 & 39 \\
\hline Bioscience & 174 & 4 \\
\hline Atmospheric Environment & 171 & 9 \\
\hline Museum International & 171 & 357 \\
\hline
\end{tabular}

Table 6. The top 10 most cited journal titles and their statistics 


\section{CONCLUSION}

This bibliometric study provides an overall picture of articles related to museum published in the databases. We observed a steady growth in the number of papers related to museum between the years of 1995 and 2014. The results are summarized as follows:

1. The literature related to museum studies seems stop to grow, but its citations grow year by year, indicating that its influences spread to other subject areas.

2. The research institutions and the productive output of the main bulk of the affiliation are located in the USA, Britain, Germany, while the most productive institutions are the Metropolitan Museum of Art, the British Museum, and the Smithsonian Institution.

3. The data about top 10 most productive authors shows that author number in English are more than those in French, while the major subject areas include art, architecture and arts \& humanities -other topics. The museum-related research will focus on the topics about biodiversity, robot tour-guide, museum collections, museum members, species, etc.

4. According to the Bradford's law, the ratio among the first 3 zones $(\mathrm{A}, \mathrm{B}, \mathrm{C})$ is approximately equal to $1: 11.5^{1}:(11.5)^{2}$. Thus, 12 core journal lists in zone A are identified. The top 3 productive journals are ARTNEWS, Museum International, Museum News, but Museum International get more attentions by its cumulated cited times.

\section{REFERENCES}

Bhattacharya, C.B., Rao, H., and Glynn, M.A., 1995. Understanding the bond of identification: An investigation of its correlates among art museum members. The Journal of Marketing, 59(4), pp. 46-57.

Borun, M., Cleghom, A., and Garfield, C., 1995. Family learning in museums: A bibliographic review. Curator: The Museum Journal, 38(4), pp. 262-270.

Brandon, L., and Wilson, G., 2005. The Canadian Museums Association Research Summit: A report. Museum Management and Curatorship, 20(4), pp. 349-358.

Burgard, W., Cremers, A.B., Fox, D., Hähnel, D., Lakemeyer, G., Schulz, D., Steiner, W., and Thrun, S., 1999. Experiences with an interactive museum tour-guide robot. Artificial intelligence, 114(1), pp. 3-55.

Chown, S.L., and Gaston, K.J., 2000. Areas, cradles and museums: the latitudinal gradient in species richness. Trends in Ecology \& Evolution, 15(8), pp. 311-315.

De Bellis, N., 2009. Bibliometrics and citation analysis: from the science citation index to cybermetrics, Scarecrow Press.

Dierking, L.D., 1989. The family museum experience: Implications from research. The Journal of Museum Education, 14(2), pp. 9-11.

Elith, J., and Leathwick, J., 2007. Predicting species distributions from museum and herbarium records using multiresponse models fitted with multivariate adaptive regression splines. Diversity and distributions, 13(3), pp. 265275.

Graham, C.H., Ferrier, S., Huettman, F., Moritz, C., and Peterson, A.T., 2004. New developments in museum-based informatics and applications in biodiversity analysis. Trends in ecology \& evolution, 19(9), pp. 497-503.

Jones, C., 1998. Museum communication and bibliometrics, London: Oxford University Press.

Kawashima, N., 1998. Knowing the Public. A Review of Museum Marketing Literature and Research 1. Museum Management and Curatorship, 17(1), pp. 21-39.

Kropf, M.B., 1989. The family museum experience: a review of the literature. The Journal of Museum Education, 14(2), pp. 5-8.

Lorente, J.-P., 2012. The development of museum studies in universities: from technical training to critical museology. Museum Management and Curatorship, 27(3), pp. 237-252.

Moksnes, A., 1995. Egg- morphs and host preference in the Common Cuckoo (Cuculus canorus): an analysis of cuckoo and host eggs from European museum collections. Journal of Zoology, 236(4), pp. 625-648.

Ponder, W., Carter, G., Flemons, P., and Chapman, R., 2001. Evaluation of museum collection data for use in biodiversity assessment. Conservation biology, 15(3), pp. 648-657.

Sterry, P., and Beaumont, E., 2006. Methods for studying family visitors in art museums: A cross-disciplinary review of current research. Museum Management and Curatorship, 21(3), pp. 222-239.

Suarez, A.V., and Tsutsui, N.D., 2004. The value of museum collections for research and society. BioScience, 54(1), pp. 6674.

Thrun, S., Beetz, M., Bennewitz, M., Burgard, W., Cremers, A.B., Dellaert, F., Fox, D., Haehnel, D., Rosenberg, C., and Roy, N., 2000. Probabilistic algorithms and the interactive museum tour-guide robot minerva. The International Journal of Robotics Research, 19(11), pp. 972-999.

Wandeler, P., Hoeck, P.E., and Keller, L.F., 2007. Back to the future: museum specimens in population genetics. Trends in Ecology \& Evolution, 22(12), pp. 634-642.

Wolfram, D., 2003. Applied informetrics for information retrieval research, Greenwood Publishing Group.

\section{APPENDIX}

\begin{tabular}{|c|c|c|c|c|c|}
\hline & $\begin{array}{c}\text { No. of } \\
\text { articles } \\
(1)\end{array}$ & $\begin{array}{c}\text { No. of } \\
\text { journal } \\
(2)\end{array}$ & $\begin{array}{c}\text { Accumulated } \\
\text { Journals ( 3) }\end{array}$ & $\begin{array}{c}(4)= \\
(1) *(2 \\
)\end{array}$ & $\begin{array}{c}(5)= \\
\text { Accumulated } \\
(4)\end{array}$ \\
\hline \multirow{5}{*}{ (A ) core } & 409 & 1 & 1 & 409 & 409 \\
\cline { 2 - 6 } & 357 & 1 & 2 & 357 & 766 \\
\cline { 2 - 6 } & 337 & 1 & 3 & 337 & 1103 \\
\cline { 2 - 6 } & 326 & 1 & 4 & 326 & 1429 \\
\cline { 2 - 6 } & 217 & 1 & 5 & 217 & 1646 \\
\hline
\end{tabular}




\begin{tabular}{|c|c|c|c|c|c|}
\hline & 215 & 1 & 6 & 215 & 1861 \\
\hline & 204 & 1 & 7 & 204 & 2065 \\
\hline & 187 & 1 & 8 & 187 & 2252 \\
\hline & 170 & 1 & 9 & 170 & 2422 \\
\hline & 146 & 1 & 10 & 146 & 2568 \\
\hline & 133 & 1 & 11 & 133 & 2701 \\
\hline & 123 & 1 & 12 & 123 & 2824 \\
\hline \multirow{39}{*}{$\begin{array}{l}\text { (B) } \\
\text { relevant }\end{array}$} & 103 & 2 & 14 & 206 & 3030 \\
\hline & 98 & 1 & 15 & 98 & 3128 \\
\hline & 97 & 1 & 16 & 97 & 3225 \\
\hline & 89 & 1 & 17 & 89 & 3314 \\
\hline & 84 & 1 & 18 & 84 & 3398 \\
\hline & 83 & 1 & 19 & 83 & 3481 \\
\hline & 81 & 1 & 20 & 81 & 3562 \\
\hline & 69 & 1 & 21 & 69 & 3631 \\
\hline & 65 & 1 & 22 & 65 & 3696 \\
\hline & 61 & 2 & 24 & 122 & 3818 \\
\hline & 59 & 1 & 25 & 59 & 3877 \\
\hline & 47 & 3 & 28 & 141 & 4018 \\
\hline & 44 & 1 & 29 & 44 & 4062 \\
\hline & 41 & 3 & 32 & 123 & 4185 \\
\hline & 39 & 1 & 33 & 39 & 4224 \\
\hline & 38 & 1 & 34 & 38 & 4262 \\
\hline & 36 & 4 & 38 & 144 & 4406 \\
\hline & 34 & 2 & 40 & 68 & 4474 \\
\hline & 33 & 1 & 41 & 33 & 4507 \\
\hline & 31 & 2 & 43 & 62 & 4569 \\
\hline & 30 & 1 & 44 & 30 & 4599 \\
\hline & 29 & 1 & 45 & 29 & 4628 \\
\hline & 27 & 4 & 49 & 108 & 4736 \\
\hline & 26 & 1 & 50 & 26 & 4762 \\
\hline & 25 & 3 & 53 & 75 & 4837 \\
\hline & 24 & 2 & 55 & 48 & 4885 \\
\hline & 23 & 1 & 56 & 23 & 4908 \\
\hline & 21 & 1 & 57 & 21 & 4929 \\
\hline & 20 & 1 & 58 & 20 & 4949 \\
\hline & 19 & 3 & 61 & 57 & 5006 \\
\hline & 18 & 6 & 67 & 108 & 5114 \\
\hline & 17 & 5 & 72 & 85 & 5199 \\
\hline & 16 & 4 & 76 & 64 & 5263 \\
\hline & 14 & 4 & 80 & 56 & 5319 \\
\hline & 13 & 3 & 83 & 39 & 5358 \\
\hline & 12 & 14 & 97 & 168 & 5526 \\
\hline & 11 & 12 & 109 & 132 & 5658 \\
\hline & 10 & 11 & 120 & 110 & 5768 \\
\hline & 9 & 14 & 134 & 126 & 5894 \\
\hline \multirow{8}{*}{$\begin{array}{l}(\mathrm{C}) \\
\text { marginal }\end{array}$} & 8 & 20 & 154 & 160 & 6054 \\
\hline & 7 & 20 & 174 & 140 & 6194 \\
\hline & 6 & 43 & 217 & 258 & 6452 \\
\hline & 5 & 64 & 281 & 320 & 6772 \\
\hline & 4 & 65 & 346 & 260 & 7032 \\
\hline & 3 & 132 & 478 & 396 & 7428 \\
\hline & 2 & 294 & 772 & 588 & 8016 \\
\hline & 1 & 931 & 1703 & 931 & 8947 \\
\hline
\end{tabular}

